\title{
The ecophysiology of cape gooseberry (Physalis peruviana L.) - an Andean fruit crop. A review
}

\section{La ecofisiología de uchuva (Physalis peruviana L.) - un frutal andino. Una revisión}
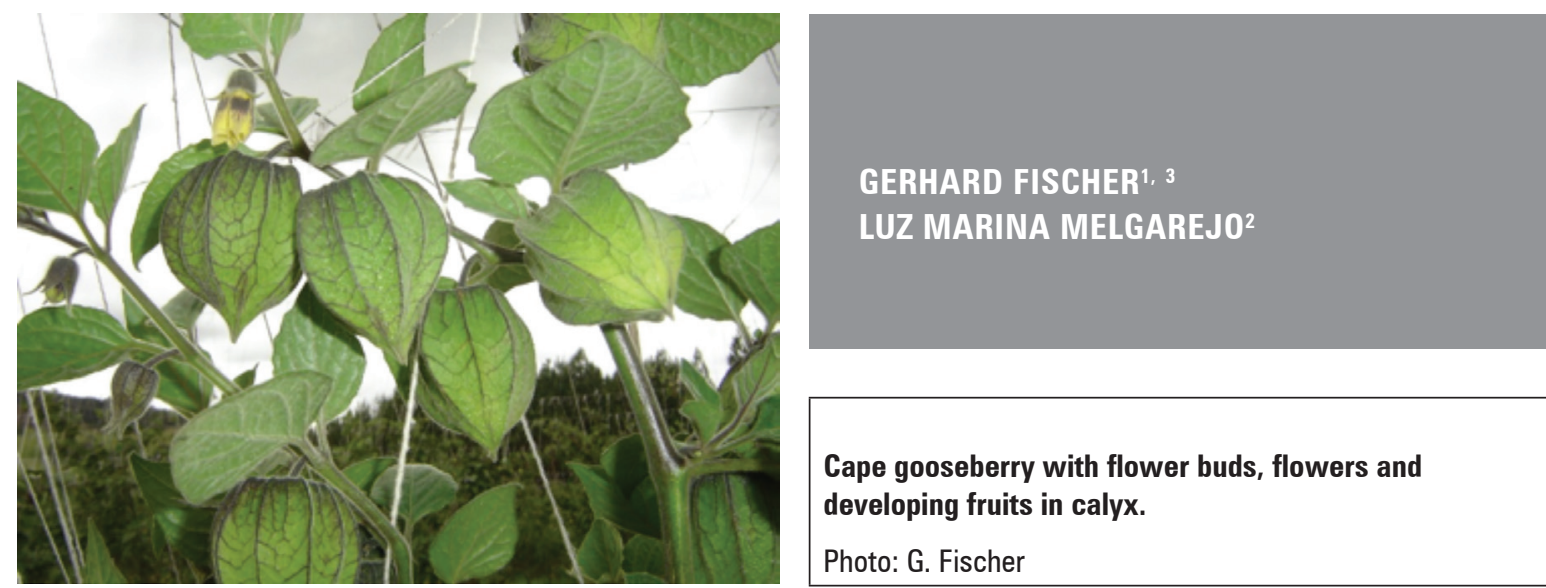

Cape gooseberry with flower buds, flowers and developing fruits in calyx.

Photo: G. Fischer

\begin{abstract}
In a literature review of the ecophysiology of cape gooseberry (Physalis peruviana L.) it was found that in Colombia this typical Andean plant adapts to a wide altitudinal range of the tropical cold climate, between 1,800 and 2,800 $\mathrm{m}$ a.s.l., with optimal medium temperatures between 13 and $16^{\circ} \mathrm{C}$ and base (minimum) temperatures for stem and fruit growth of 6.3 and $1.9^{\circ} \mathrm{C}$, respectively. However, this fruit does not withstand temperatures $<0^{\circ} \mathrm{C}$. The Andean conditions of the tropics such as high solar radiation and rather short day lengths $<12$ hours favor flower initiation. A duration of 1,500-2,000 hours year ${ }^{-1}$ of direct sunshine are the most favorable for the size, quality and ripening of the fruit. Under field conditions in Bogota we measured a photosynthesis rate of $\mathrm{A}=10.545 \mu \mathrm{mol} \mathrm{CO} \mathrm{m}^{-2} \mathrm{~s}^{-1}$ and light compensation point $\mathrm{Ic}=13.645 \mu \mathrm{mol}$ photons $\mathrm{m}^{-2} \mathrm{~s}^{-1}$. As this species with an indeterminate growth habit requires a constant supply of water, while high amounts or heavy rains after a dry season cause cracking of the fruits, the plant does not tolerate waterlogging for more than 4 days. Cape gooseberry is classified as moderately tolerant to salinity and $30 \mathrm{mM} \mathrm{NaCl}$ curiously promotes growth, since the plant has mechanisms such as increased antioxidant activity to protect against saline conditions.
\end{abstract}

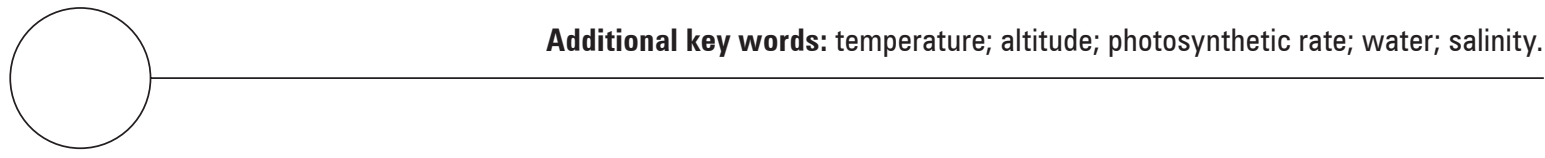

\footnotetext{
1 Independent Consulter, Emeritus Researcher of Colciencias, Bogota (Colombia). ORCID Fischer, G.: 0000-0001-8101-0507

2 Universidad Nacional de Colombia, Facultad de Ciencias, Departamento de Biología, Laboratorio de Fisiología y Bioquímica Vegetal, Bogota (Colombia). ORCID Melgarejo, L.M.: 0000-0003-3148-1911

3 Corresponding author. gerfischer@gmail.com
} 


\section{RESUMEN}

Con el fin de revisar la literatura sobre la ecofisiología de la uchuva se encontró que esta típica planta andina en Colombia se adapta a un rango amplio de altitud de clima frío tropical, es decir entre 1.800 y 2.800 metros sobre el nivel del mar (msnm), con temperaturas medias óptimas entre 13 y $16^{\circ} \mathrm{C}$ y temperaturas bases (mínimas) para el crecimiento del tallo y del fruto relativamente bajas, 6,3 y $1,9^{\circ} \mathrm{C}$, respectivamente, sin embargo no tolera temperaturas $<0^{\circ} \mathrm{C}$. Igualmente, las condiciones andinas del trópico como es la radiación solar alta y las longitudes del día $<12$ horas, más bien cortas, favorecen el inicio de la floración. Entre 1.500 y 2.000 horas año-1 de brillo solar (luz solar directa) son los más favorables para el tamaño, calidad y maduración del fruto. Bajo condiciones de campo en Bogotá, se midió una tasa de fotosíntesis $\mathrm{A}=10,545 \mu \mathrm{mol} \mathrm{CO} \mathrm{m}^{-2} \mathrm{~s}^{-1}$ y punto de compensación por luz Ic $=13,645$ $\mu \mathrm{mol}$ fotones $\mathrm{m}^{-2} \mathrm{~s}^{-1}$. Como planta con un hábito de crecimiento indeterminado, la provisión constante de agua es indispensable, mientras altas cantidades o lluvias fuertes, después de una época seca, causan el rajado de los frutos, igualmente como la planta no tolera más que 4 días el anegamiento. La uchuva es calificada como una planta moderadamente tolerante a la salinidad y $30 \mathrm{mM} \mathrm{NaCl}$ curiosamente fomentan el crecimiento, teniendo mecanismos, como el aumento de la actividad antioxidante, para protegerse contra condiciones salinas.

Palabras clave adicionales: temperatura; altitud; tasa fotosintética; agua; salinidad.

Received for publication: 29-01-2020 Accepted for publication: 30-03-2020

INTRODUCTION

Ecophysiology studies the environmental effects on plant physiology, describing the physiological mechanisms during plant growth and development and their interactions with biotic and physicochemical environmental factors (Lambers et al., 2008). Climatic factors influence crops at the same time, and when they become stressful as occurs during excessive heat, drought, strong ultraviolet light and wind, and other environmental stressors, their action can be very damaging to the plant (Mittler, 2006). No factor alone impacts physiology and performance (Fischer et al., 2016).

Site growth conditions, like climate, soil and crop management, affect the size of the plant, the duration of its phenological stages, and the period and volume of the harvest (Fischer et al., 2016; 2018) This means that planting a crop in an unsuitable ecophysiological site increases the production costs by reducing economic success (Fischer and Orduz-Rodríguez, 2012).

In recent decades, many environmental imbalances caused by deforestation and increased greenhouse gas emissions have caused significant changes in worldwide climatic dynamics (Menezes-Silva et al., 2019). These have major implications for global food security affecting, among other factors, the growth and productivity of plants (Dhankher and Foyer, 2018). For these climate changes, UNEP (2019) predicted that near the end of the $21^{\text {st }}$ century (2100) the global average temperature will increase by $3.2^{\circ} \mathrm{C}$, if governments do not take more stringent measures to control the greenhouse effect. Shukla et al. (2019), in their IPCC technical summary, stated clearly that fruits and vegetables, as key elements of healthy diets, are susceptible to climate change and that production, quality, and crop suitability will decline as temperatures increase, particularly in the tropics and semi-tropical regions.

Especially for the tropical Andes, the average precipitation will increase by 20-25\% (Marengo et al., 2011). Likewise, they affirm that in the high Andean zones - where the greatest production of cape gooseberry is concentrated - the magnitude of the warming will tend to be greater than in the low zones. Baldwin et al. (2019) reports that extreme weather events, including heat waves and droughts, are expected to increase in occurrence and severity as atmospheric $\mathrm{CO}_{2}$ rises.

The cape gooseberry (Physalis peruviana L., Solanaceae) is native to the South American Andes (Fischer and Melgarejo, 2014), in Peru, Brazil, Chile, Ecuador, and Colombia. Commercial production has spread far 
more widely than these previously named countries, including now Kenya, South Africa, Egypt, Zimbabwe, New Zealand, Australia, India, China and Hawaii, and now also in Caribbean countries (Fischer et al., 2014; Ramadan and Mörsel, 2019). The CABI Invasive Species Compendium (2019) reports the appearance of $P$. peruviana in most countries of the world, classifying it as a plant of the high tropics that also grows well in the subtropics and in the not excessivley cold conditions of the temperate climate, where it behaves like an annual plant.

In Colombia, according to Agronet (2019) data for 2017 the annual production of cape gooseberry fruits was 18,889 t over a harvested area of 1,259 ha, located mainly in the departments of Boyaca ( $616 \mathrm{ha}$ ), Cundinamarca (465 ha), Antioquia (149 ha) and Nariño (130 ha). Colombia is not only the largest producer, but also an exporter of this fruit (with USD 32.4 million in 2018), especially to European countries, primarily the Netherlands, Belgium, the United Kingdom and Germany (Agronet, 2019).

The plant develops as a semi-shrub, semi-perennial with an indeterminate growth habit (Ramírez et al., 2013), and attains commercial fruit production during the first 18 months of the crop. It reaches a height of 1-1.5 m, generally forming four erect productive branches (Fischer et al., 2014). If not controlled, the plant can become invasive displacing other crops and be considered a weed (CABI Invasive Species Compendium, 2019).

On the aerial part of the plant and particularly on the leaves - which are simple, heart-shaped and alternate - the cape gooseberry develops full pubescence (Fischer and Miranda, 2012) that protects against sudden changes between day/night temperatures and high UV radiation from the tropical highlands (Fischer, 1995).

The flowers are hermaphroditic with a yellow tubular corolla and are solitary, while the calyx with a cupuliform structure (Nocetti et al., 2020), consists of five persistent sepals (or modified leaves). These form a husk $4-5 \mathrm{~cm}$ long that encloses and protects the fruit (against pests, UV light, rain, hail and cold) until maturity. It then changes into a translucent and parchment husk (Fischer and Miranda, 2012), due to the degradation of its chlorophyll and the translocation of almost all its carbohydrates, especially during the first $20 \mathrm{~d}$ of development of the fruit, (Fischer et al., 2015). The development of the fruit, according to the agro-ecological condition, takes $60-80 \mathrm{~d}$ (Fischer and Miranda, 2012).

The almost round fruits of cape gooseberry are yellow-orange berries with a diameter of $1.25-2.5 \mathrm{~cm}$, weighing 4 - $10 \mathrm{~g}$ (Dostert et al., 2012); while the 'Kenya' ecotype is up to twice this size, also showing a polyploid chromosomal number of twice $(2 n=48)$ that of the Colombian wild ecotypes $(2 n=24)$. The commercial ecotype 'Colombia' has a chromosomal endowment of $2 n=32$ (Rodríguez and Bueno, 2006). The fruit contains up to 350 seeds, which are small (about $1.1 \mathrm{mg}$ in weight), flattened and lenticular (Fischer, 2000a; Fischer et al., 2007).

The fruits of the cape gooseberry contain multiple health properties due to the elevated content of antioxidants, minerals and vitamins (Ramadan and Mörsel, 2019). It is an antioxidant and anti-inflammatory (Puente et al., 2019) and stands out for its contents of provitamin A (648-5,000 IU), ascorbic acid 11-43 $\mathrm{mg} / 100 \mathrm{~g}$ fresh weight and iron (1.1-1.7 mg), 13$15^{\circ}$ Brix (Fischer et al., 2011). Akbaba (2019) emphasizes the important medical use of this fruit in the control of hepatitis, malaria, rheumatism, dermatitis, diabetes and weight loss. Furthermore, the sap of the plant synthesizes withanolides that serve as repellents against coleopteran pests (Fischer et al., 2011).

Ecofisiological studies and related topics are of special importance for finding adaptation strategies for the crops to changing environmental conditions (SánchezReinoso et al., 2019; Cardona et al., 2016; ClevesLeguízamo et al., 2017), therefore the objective of this review is to report on the current state of knowledge of the ecophysiological factors in the growth and physiology of the cape gooseberry plant and thus facilitate significant decisions for research and production of this important Andean fruit species.

\section{ENVIRONMENTAL FACTORS}

\section{Temperature}

Temperature is the most complex factor in ecophysiology (Gariglio et al., 2007). Like all plants, the cape gooseberry needs a base (or minimum) temperature to begin growth (Parra et al., 2015). This was established by Salazar et al. (2008) at $6.3^{\circ} \mathrm{C}$ by the appearance of nodes on the stem. This temperature confirms the species' good adaptation to cold climatic zones in Colombia (Fischer and Miranda, 2012). 
The cape gooseberry base temperature for the different phenological stages in its reproductive phase (investigated so far in a few species) is shown in Table 1. Salazar et al. (2008) calculates a light extinction coefficient (k) of 0.469 , a light use efficiency (LUE) of 0.46 $\mathrm{g} \mathrm{MJ}^{-1}$ for the vegetative state and $2.62 \mathrm{~g} \mathrm{MJ}^{-1}$ for the reproductive phase, registering $69 \%$ of the plant's total dry matter (DM) for the distribution in the fruit (Tab. 1).

In a cape gooseberry experiment, Aguilar-Carpio et al. (2018) applied the base temperature of $6.3^{\circ} \mathrm{C}$ for stem growth in order to calculate the heat units $(\mathrm{HU}=$ [(Tmax - Tmin)/2] - 6.3). Comparing different concentrations of Steiner's nutrient solution Salazar et al. (2008) found that the solution of $150 \%$ required only 1,370 HU, compared with 1,435 and 1,527 HU at 100 and $50 \%$ of the Steiner's solution, respectively. Therefore, the plant had $15 \mathrm{~d}$ of precocity in fruit production compared to the $50 \%$ solution.

The calculated base temperature of $1.9^{\circ} \mathrm{C}$ for the development of the fruit is real, taking into account that they resist temperatures as low as $1.6^{\circ} \mathrm{C}$ during storage (Alvarado et al., 2004) without physiological damage.

The average temperature range guaranteeing good adaptation and production of cape gooseberry at a Colombian site is 13 to $16^{\circ} \mathrm{C}$ (Fischer and Miranda, 2012). However, Carillo-Perdomo et al. (2015) reported an optimal average temperature of $18^{\circ} \mathrm{C}$. Possibly, the most favorable temperatures for the production and quality of cape gooseberry fruits also depend on the ecotype or genotype, because in Cundinamarca at $17.5^{\circ} \mathrm{C}$ medium temperature in Subia $(1,900 \mathrm{~m}$ a.s.1.) the fruits of the Colombia ecotype were of a smaller size and weight (5.12 g), compared to the site with more elevation, San Raimundo (2,100 m a.s.1., $16.0^{\circ} \mathrm{C}$ ), with a weight of $6.95 \mathrm{~g}$ (Mazorra et al., 2003).
From $30^{\circ} \mathrm{C}$ an inhibition of flowering has been observed (Wolff, 1991). However, optimal temperatures for seed germination in cape gooseberries collected in Sertão (Rio Grande do Sul, Brazil) and Capelinha (Minas Gerais, Brazil), were 27 and $32^{\circ} \mathrm{C}$, with 98 and $96 \%$ germination respectively (Nunes et al., 2018). Diniz et al. (2020) observed that cape gooseberry seeds germinated within a wide range of temperatures between 15 and $30^{\circ} \mathrm{C}$, with the best results at $25^{\circ} \mathrm{C}$ of constant temperature or $20-30^{\circ} \mathrm{C}$ alternating temperatures, under a lighting of $8 \mathrm{~h} \mathrm{~d}^{-1}$ light.

Constant night temperatures $<10^{\circ} \mathrm{C}$ impair plant development (National Research Council, 1989). Likewise, in a growth chamber at a constant temperature of $12^{\circ} \mathrm{C}$, the cape gooseberry did not prosper because of a reduction of the amount of fruit set and the formation of very flattened fruits that are not marketable (Pacheco and Sáenz, 1991).

In a study of agricultural zoning of climatic risk in the Southeast of Brazil, 10\% of land suitable for the cultivation of $P$. peruviana was identified when taking into account air temperature between 13 and $18^{\circ} \mathrm{C}$ and an annual precipitation of $1,000-2,000 \mathrm{~mm}$. This ruled out regions superior to $30^{\circ} \mathrm{C}$ and inferior to $13^{\circ} \mathrm{C}$ (Aparecido et al., 2019).

The fruit of the cape gooseberry is protected by a calyx against large variations in temperature and that encloses the fruit throughout its development. Fischer (1995) found that in Villa de Leyva (Boyaca, Colombia), at 2,300 $\mathrm{m}$ a.s.l., the temperature at noon was up to $5^{\circ} \mathrm{C}$ lower inside this organ than that outside (Fig. 1), but this protective effect did not appear at a higher and colder site in Tunja at 2,690 $\mathrm{m}$ a.s.l. Apart from the extreme temperatures, the calyx protects the fruit against sunburn, hail and mechanical damages such as air-distributed diseases, insects, and birds (Fischer et al., 2011).

Table 1. Base temperature and dry matter distribution for the different phenological stages of the cape gooseberry (Salazar et al., 2006).

\begin{tabular}{|c|c|c|c|c|}
\hline Phenological state & Base temperature $\left({ }^{\circ} \mathrm{C}\right)$ & \multicolumn{3}{|c|}{ Distribution of DM in the different aerial organs } \\
\hline Appearance of knots on stem & 6.3 & \multirow{2}{*}{ Vegetative state } & Leaves & $72 \%$ \\
\hline First flower bud appearance & 10.8 & & Stem & $28 \%$ \\
\hline Time between first flower bud until first flower & 5.6 & \multirow{3}{*}{ Reproductive state } & Leaves & $9 \%$ \\
\hline Time between first flower until first fruit & 10.5 & & Stem & $22 \%$ \\
\hline Time between first fruit and ripe fruit & 1.9 & & Fruits & $69 \%$ \\
\hline
\end{tabular}



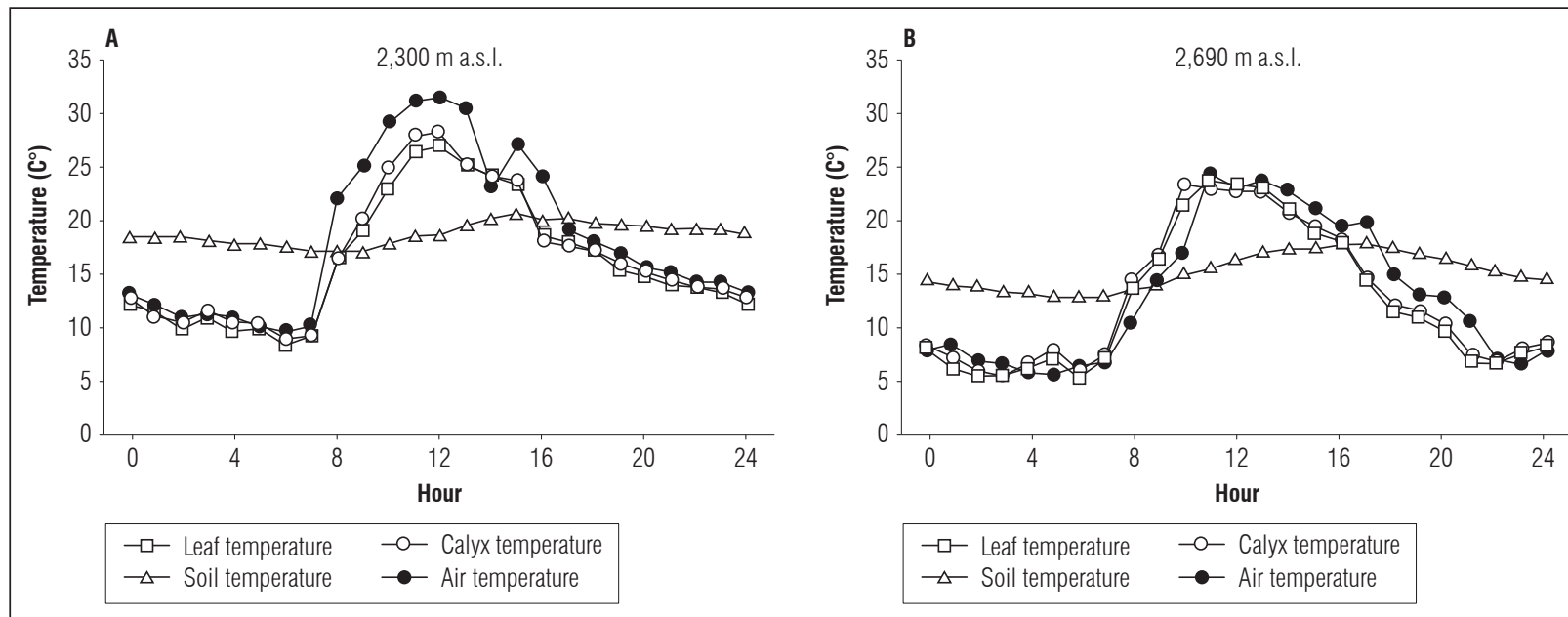

Figure 1. Changes in air temperature in the leaf shoot, inside the calyx, and at $10 \mathrm{~cm}$ soil depth for 24 hours in cape gooseberry (Physalis peruviana L.) in a lot in (A) Villa de Leyva (2,300 $\mathrm{m}$ a.s.I., $\left.17.4^{\circ} \mathrm{C}, 66.6 \% \mathrm{RH}\right)$ and $(\mathrm{B})$ Tunja $(2,690 \mathrm{~m}$ a.s.I., $12.5^{\circ} \mathrm{C}$ and $79.0 \% \mathrm{RH}$ ) in Boyaca Colombia (Fischer, 2019).

The temperatures of the root surroundings exert a great influence on the metabolism and the functions of the roots, for which Fischer and Melgarejo (2014) reported that temperatures between 15 and $22^{\circ} \mathrm{C}$ of the cape gooseberry roots best favor leaf growth, while at $8^{\circ} \mathrm{C}$ the development of the plant is very poor (related to the longitudinal growth of branches, insertions and leaf surface). Possibly this is induced by the higher viscosity of the water and the lower permeability of the membranes at this low temperature. The membrane lipids become less fluid at these low temperatures and their protein components no longer function properly (Taiz and Zeiger, 2010), resulting in less absorption of water and nutrients and a reduction in growth and photosynthesis of the plant (Fischer et al., 2000a).

A herbaceous plant such as cape gooseberry suffers from frost that causes burns and dark colorations, especially in young plants, flowers, new shoots, leaves and calyces at $2^{\circ} \mathrm{C}$ (Fischer and Melgarejo, 2014). Irreparable burns occur at temperatures below $0^{\circ} \mathrm{C}$ (Carillo-Perdomo et al., 2015). In the plantations of the Colombian Cundinamarca-Boyacense zone from 2,400 $\mathrm{m}$ a.s.1., there are drops in temperature, especially in the early morning, that coincide with dry weather and a clear sky and that are often without wind and these temperature drops induce radiation frost (Torres et al., 2016). The cape gooseberry is capable of a resprouting of the basal shoots if the frost is short (up to $-6^{\circ} \mathrm{C}$ ) (Fischer and Melgarejo, 2014).

\section{Light}

Solar radiation plays a crucial role as an energy source for the production of DM and fruits of the cape gooseberry (Fischer and Orduz-Rodríguez, 2012). The plant depends on visible light to maintain a positive carbon balance through photosynthesis (Taiz and Zeiger, 2010). Consequently, the DM of the plant depends on the incidence and absorbed radiation, in addition to the ability to convert the radiation to carbohydrates through photosynthesis (Gariglio et al., 2007).

The amount of light (light intensity or irradiance), the quality of light (wavelength) and the photoperiod (light hours/day) are some of the light factors perceived by the cape gooseberry (Fischer and Melgarejo, 2014), taking into account that the solar radiation that falls on the green fruit calyx and the two adjacent leaves are decisive for fruit maturation and quality (Fischer et al., 2015). In general, Mora et al. (2006) estimate that for cape gooseberries 1,500 to 2,000 h of direct sunlight per year are the most favorable for the size, quality and ripening of the fruit. This characterizes the cape gooseberry as a light demanding plant (Carrillo-Perdomo et al., 2015).

Under conditions of restricted luminosity - as in the case of a dense plantation or in a greenhouse - the cape gooseberry reacts with an elongation of the branches compared to plants in the open field that 
are well-distanced and where a higher incidence of UV light exists (Fischer, 2000b).

In the case of direct solar radiation onto the cape gooseberry fruit in which the calyx has been removed, the first author of this review found that in Villa de Leyva (Boyaca, 2,300 $\mathrm{m}$ a.s.1.) the fruit epidermis was burned after one week and mined by beetle larvae. This underlines the importance of the calyx against direct sunstroke and the production of a withanolide repellent at the base of the calyx against insects. Furthermore, as previously mentioned, the calyx protects against an extreme increase in the temperature of the fruit, thus, avoiding its cracking (Peet, 2009).

In some studies related to foliar photosynthesis (gas exchange) in plants grown under field conditions in Bogota, the authors of this document found that by constructing light response curves (range from 0 to 1,400 $\mu \mathrm{mol}$ photons $\mathrm{m}^{-2} \mathrm{~s}^{-1}$; Cref constant $400 \mathrm{ppm}$, constant $18^{\circ} \mathrm{C}$ ) that the plants have a photosynthesis rate $\left(\mathrm{A}=10.545 \mu \mathrm{mol} \mathrm{CO} \mathrm{m}^{-2} \mathrm{~s}^{-1}\right.$; light compensation point $\mathrm{Ic}=13.645 \mu \mathrm{mol} \mathrm{CO} \mathrm{m}^{-2} \mathrm{~s}^{-1}$ ); light saturation constant (defined as $1 / 2$ of the saturating photon flux density equal to $207.91 \mu \mathrm{mol}$ photons $\mathrm{m}^{-2}$ $\mathrm{s}^{-1}$; dark respiration $\left.\mathrm{Rd}=0.6496 \mu \mathrm{mol} \mathrm{CO} \mathrm{Cm}^{-2} \mathrm{~s}^{-1}\right)$; and apparent quantum yield $\left(\Phi=0.03011 \mu \mathrm{mol} \mathrm{CO}_{2}\right.$ $\mu \mathrm{mol}^{-1}$ photons) (Fig. 2). Additionally, through the chlorophyll a fluorescence measurement methodology a maximum photochemical efficiency of photosystem II (Fv/Fm) of 0.82 was found, which is an indicator of a good state of operation of photosystems (Fischer and Melgarejo, 2014).

When net photosynthesis response curves were constructed at different $\mathrm{CO}_{2}$ concentrations (Ci: 0 to 600 ppm; Cref 400 ppm, constant $18^{\circ} \mathrm{C}$, constant PAR 600 $\mu \mathrm{mol}$ photons $\mathrm{m}^{-2} \mathrm{~s}^{-1}$ ), in the same plants and leaves where light curves were constructed, and using adjustments by the Farquhar FvCB model, the authors recorded a maximum carboxylation rate of $\mathrm{RuBis} C \mathrm{C}$ $\mathrm{Vc}_{\max }=75.70 \mu \mathrm{mol} \mathrm{CO} \mathrm{Cm}^{-2} \mathrm{~s}^{-1}$ and a maximum rate of regeneration of ribulose-1,5-bisphosphate controlled by electron transport $\mathrm{J}_{\max }=288.09 \mu \mathrm{mol} \mathrm{CO}_{2}$ $\mathrm{m}^{-2} \mathrm{~s}^{-1}$.

The cape gooseberry behaves like a facultative (or quantitative) short day plant. Heinze and Midash (1991) found that an 8-h photoperiod shortens the juvenile phase producing faster flower induction than a plant under $16 \mathrm{~h} \mathrm{~d}^{-1}$ light. This shorter photoperiod also develops more elongated internodes. This behavior as a short-day plant coincides with other species that originate in low latitudes such as corn, rice, soybean varieties and coffee, and other species (Dwivedi and Dwivedi, 2012).

P. peruviana seeds show low germination percentages in the absence of light. Nunes et al. (2018) observed germination percentages of $97 \%$ in a light regime of 8 $\mathrm{h}$ or more daily, indicating that the seed is photoblastically positive.

\section{Ultraviolet (UV) light}

Due to its growth in high-altitude tropical areas, the cape gooseberry receives large amounts of UV light for which it is adapted through its pubescent green epidermis, includaing a calyx that protects the fruit against this type of radiation (Fischer et al., 2016). In a study at two altitudes in Boyaca, Fischer (1995) found that these plants develop a shorter stem with

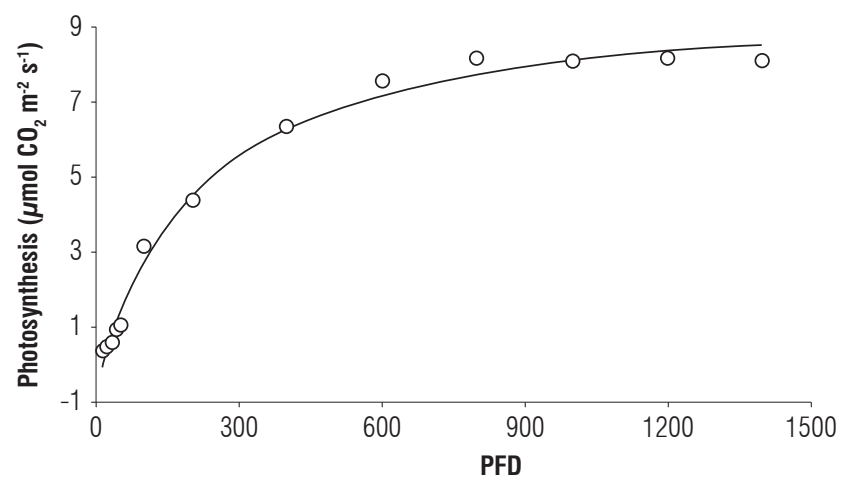

$P=-0.6496+10.545 * P F D /(207.91+P F D)$

Figure 2. Response of net photosynthesis to light in leaves of cape gooseberry plants. Fitting a hyperbolic Michaelis-Menten model. Photon flux density $\left(\mu \mathrm{mol}\right.$ photons $\left.\mathrm{m}^{-2} \mathrm{~s}^{-1}\right)$. 
1,399 $\mathrm{mW} \mathrm{m}^{-2}$ UV-B (at 2,690 $\mathrm{m}$ a.s.1.) than with $1,294 \mathrm{~mW} \mathrm{~m}^{-2}$ UV-B (at 2,300 $\mathrm{m}$ a.s.1.). Fischer and Melgarejo (2014) proposed three possible causes for this phenomenon: (1) the increase in UV-B radiation (280-320 nm) can reduce the longitudinal growth of the stem due to the reduction of auxins (Kulandaivelu et al., 1989); (2) the lower night temperature at 2,690 $\mathrm{m}$ a.s.l. markedly decreases stem growth; and (3) the reduced atmospheric pressure at the higher altitude with $736 \mathrm{mb}$ compared to $776 \mathrm{mb}$ at the lower altitude could have negative effects on the elongation of the internodes.

\section{Altitude}

The increase in tropical altitude is characterized by a decrease in the average temperature $\left(6^{\circ} \mathrm{C} / 100 \mathrm{~m}\right)$, increased radiation (mainly UV-B) and wind incidence, and a reduction in precipitation that reduces the growth rate and leaf area producing thicker leaves compared to lower elevation sites (Fischer, 2000b). Thus, the leaves increase the number of layers of the parenchyma, forming a thicker cuticle with greater pubescence, which better filters the mutagenic effects of high UV radiation and improves the phytosanitary status of the cape gooseberry (Fischer and Orduz-Rodríguez, 2012).

Cape gooseberry is a crop adapted to a wide range of altitudes that can reach up to $3,300 \mathrm{~m}$ a.s.l. in Ecuador (Carrillo-Perdomo et al., 2015). Fischer and Miranda (2012) characterize between 1,800 and 2,800 m a.s.l. for Colombia altitudes that are the most commercially suitable for this plant. They specify that altitudes between 2,200 and 2,400 $\mathrm{m}$ a.s.l. can have the best production, if the microclimate and plantation management are adequate.

Possibly due to the reduced partial pressure of gases such as $\mathrm{CO}_{2}$ and $\mathrm{O}_{2}$ at a higher altitude, cape gooseberries develop a greater number of stomata per leaf area at these elevations. Fischer (1995) found in African ecotypes in Kenya and South Africa that 678 and 719 stomata $/ \mathrm{mm}^{2}$ leaf area at $2,690 \mathrm{~m}$ a.s.l. were typical. But they found only 564 and 507 stomata at 2,300 $\mathrm{m}$ a.s.1., respectively. However, this behavior did not show up in the Colombian ecotype that had 534 and 547 stomata at the two respective altitudes. Also, the same author recorded that the roots grew smaller and more superficial in the highest areas $(2,690 \mathrm{~m}$ a.s.1.), because the soil cools down so much at night at this altitude (Fig. 1), that it must take better advantage of solar heating during the day.
In the higher and colder zone $\left(2,690 \mathrm{~m}\right.$ a.s.1., $\left.12.5^{\circ} \mathrm{C}\right)$ the contents of sucrose and soluble solids, and also the number and weight of the seeds of the gooseberry fruit decreased significantly. Thus, the first production peak is postponed, although, the production cycle can be longer, about 2 years, compared to a lower site $\left(2,300 \mathrm{~m}\right.$ a.s.1., $\left.17.4^{\circ} \mathrm{C}\right)$ that takes only 1.5 years (Fischer et al., 2007). For that, latter authors suppose that at the lower altitude the higher sucrose content, the most common sugar in this fruit (Fischer et al., 2015), was fostered by the higher seed number and weight which probably increased the sink strength and the greater influx of sucrose in the fruit, But also the higher temperature at the lower site probably promoted the hydrolysis of starch to soluble sugars. This was found by Mayorga et al. (2020) in curuba fruits that were grown at $2,006 \mathrm{~m}$ a.s.1. $\left(19.4^{\circ} \mathrm{C}\right.$ day time temperature) and 2,498 $\mathrm{m}$ a.s.1. $\left(14.9^{\circ} \mathrm{C}\right)$ in Pasca (Cundinamarca, Colombia).

In the lower and warmer zone the fruits contained higher concentrations of provitamin A carotenoids (alpha- and beta-carotene) than at the higher site. This was a result that Fischer et al. (2000b) did not observe for ascorbic, citric and malic acids that were not influenced by altitude.

\section{Water}

Since in a plant of indeterminate growth, as in many nightshades, vegetative and reproductive development occur at the same time (Ramírez et al., 2013), the cape gooseberry needs a constant supply of water. The most demanding phases between bud sprouting, flowering and fruit filling (Fischer and Miranda, 2012), require uniformly distributed rainfall of between 1,000 and $1,800 \mathrm{~mm}$ year ${ }^{-1}$ of precipitation per year.

During the initial growth of a plantation, the cape gooseberry is water demanding (Carillo-Perdomo et al., 2015). This contrasts with fruit harvesting when the crop needs water levels below field capacity so as not to harm the quality of the fruit (Torres et al., 2004) and stagnate the vegetative growth of the plant (Fischer, 2000a).

The cape gooseberry fruit contains $80 \%$ water, and this amount is increased or reduced according to the water available to the plant (Fischer and Melgarejo, 2014). The size of the fruit depends highly on the soil humidity provided by irrigation and rain (Fischer, 
2005). The fruit constantly accumulates water and sucrose until its organoleptic maturity (yellow-orange color), during which it would take advantage of irrigation until harvest (Fischer and Martínez, 1999). However, this is at the cost of postharvest quality and durability.

In a study of irrigation frequencies and levels with calcium applications on cape gooseberry plants, Álvarez-Herrera et al. (2015) found that one irrigation every $4 \mathrm{~d}$ produced fruits of greater fresh mass, while irrigation every $14 \mathrm{~d}$ caused fruits of smaller size. However, the percentage of small fruits was reduced when applying Ca (50 or $\left.100 \mathrm{~kg} \mathrm{ha}^{-1}\right)$. The cape gooseberry responds favorably to irrigation, also in amounts that exceed the crop evapotranspiration value. With an irrigation coefficient of 1.3 , the quantity of fruits increased increasing production per plant (Álvarez-Herrera et al., 2015), whereas the irrigation coefficient of 1.1 exhibited maximum values of $\psi_{\text {leaf }}$ and $\psi_{\text {stem }}$ (Álvarez-Herrera et al., 2019). The irrigation coefficient of 1.1 every $4 \mathrm{~d}$ had the second highest irrigation water-use efficiency (WUEi) and represented the most appropriate water level for cape gooseberry growing because this generated the highest amount of large and marketable fruits and the smallest number of cracked fruits (Álvarez-Herrera et al., 2019).

The cracking of the cape gooseberry fruit is the physiological disorder most related to excess water due to overly abundant rains or irrigation. This is especially true when interrupting a dry season and, especially during the rainy seasons. The fruits rejected by exporters because of cracking can reach 50\% (Fischer, 2005). This physiological damage occurs particularly in large fruits, with high volume and weight (Gordillo et al., 2004). Plant breeding programs must take this situation into account and orient breeding programs to the size of this organ, an attribute for which the expression of genes is highly dependent on environmental conditions (Trevisani et al., 2017).

Supposedly, elevated water content and the high concentration of solutes exert high pressure on the epidermis of the fruits (Peet, 2009), and because they cannot resist the pressure, they crack (Fischer, 2005). This situation is accentuated if there are only a few fruits on the plant, as for example in the first production cycle (Gordillo et al., 2004). The relationship between the leaf area and the number of fruits during the formation of the first harvest is high, increasing the influx of carbohydrates to the fruit (Torres et al.,
2016). Gordillo et al. (2004) observed two types of cracking, deep (splitting) and superficial (cracking).

Therefore, fruit growers prefer to eliminate the first flowers of the plant, and to also maintain an adequate level of nutrients that promotes firmness and an extension of the epidermis, such as calcium, boron and magnesium (Garzón-Acosta et al., 2014; Cooman et al., 2005). Álvarez-Herrera et al. (2012) reported 38\% cracking in cape gooseberry fruits without adding $\mathrm{Ca}$ to the substrate, but this dropped to $27 \%$ after applying $100 \mathrm{~kg} \mathrm{ha}^{-1}$ of calcium.

\section{Relative humidity (RH)}

A RH between 70 and $80 \%$ is optimal for growth and production of the cape gooseberry (Fischer and Miranda, 2012). Higher RH favors the incidence of diseases such as Botrytis sp., Phoma sp. and Xanthomonas $\mathrm{sp}$. Serious leaf and calyx damage during high $\mathrm{RH}$ causes Cercospora sp., preventing fruit export with calyx (Fischer et al., 2011). Prolonged periods of high $\mathrm{RH}$ inhibit the plant's potential to form a thick cuticle or it can modify its composition, reducing cuticular protection (Opara et al., 1997).

Fischer (2005) reported that high RH (>95\%) occurring for 6 consecutive hours in the field, with or without rain suppresses transpiration of the fruit causing high pressure on the epidermis that consequently can crack.

\section{Waterlogging}

As a solanaceous plant the cape gooseberry does not tolerate waterlogging or flooding conditions for longer than $4 \mathrm{~d}$ in plants submitted for $0,2,4,6$ and 8 $\mathrm{d}$ to waterlogging $(5 \mathrm{~cm}$ above the substrate of the pot) (Aldana et al., 2014). After $6 \mathrm{~d}$ of waterlogging the plants showed significant reductions in vegetative growth (plant height, number of leaves, leaf area, diameter of the basal stem), including the number of nodes on the branches. Consequently, the number of flower buds, flowers and fruits decrease, and taking into account that at each node of the fruiting branches the reproductive organ forms (Ramírez et al., 2013). The chlorophyll index is highly reduced especially from the $29^{\text {th }}$ day after the beginning of the experiment, so that after $50 \mathrm{~d}$ the plants that were waterlogged for $8 \mathrm{~d}$ register a SPAD index of 17.48, compared to the control (35.85), in addition to severe leaf wilt (Aldana et al., 2014). Sánchez-Reinoso et al. 
(2019) observe with increasing waterlogging periods $(0,3,6$ and $9 d)$ great chlorophyll content reductions, especially at 6,12 and $18 \mathrm{~d}$ after the beginning of the waterlogging period. The effect of waterlogging on the development of the cape gooseberry DM is clear (Fig. 3).

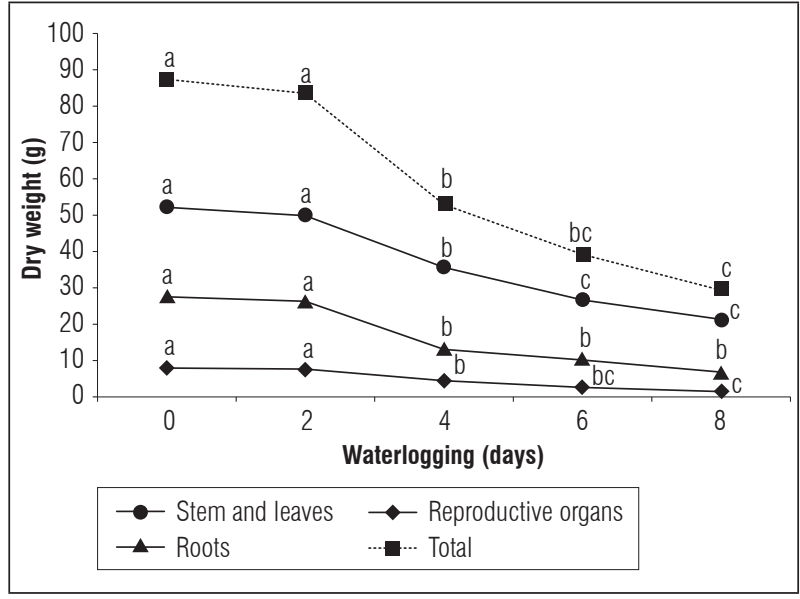

Figure 3. The dry weight of organs (stem and leaves, reproductive organs [flower buds, flowers and fruits] and roots) of cape gooseberry plants in $10 \mathrm{~L}$ plastic pots after $50 \mathrm{~d}$ of the beginning of waterlogging of $0,2,4,6$ and $8 \mathrm{~d}$, modified from data of Aldana et al. (2014). Means with different letters of the same organ indicate significant differences after the Tukey test $(P \leq 0.05)$.

Due to the high incidence of Fusarium spp. in cape gooseberry plantations in the country caused by torrential rains, Villareal-Navarrete et al. (2017) flooded cape gooseberry plants in $2 \mathrm{~L}$ plastic pots for $6 \mathrm{~d}$, where the substrate was or was not inoculated with Fusarium oxysporum. Each of the two factors, waterlogging and Fusaium, alone did not show significant negative effects on plant growth for $30 \mathrm{~d}$, but the combination of the two stresses reduced root related variables (root dry weight, length, and neck diameter), and leaf area. In addition, the ratio of root dry weight to aerial parts of the plant decreased dramatically, from 0.45 to 0.14 . In this experiment, a heavy reduction of stomatal conductance and transpiration rate is seen in addition to a strong decrease in the rate of photosynthesis in plants flooded and affected by Fusarium $\left(1.75 \mu \mathrm{mol} \mathrm{CO} \mathrm{Cm}^{-2} \mathrm{~s}^{-1}\right)$, compared to control plants $\left(5.06 \mu \mathrm{mol} \mathrm{CO} \mathrm{m}^{-2} \mathrm{~s}^{-1}\right)$. This means a $35 \%$ reduction when plants are affected by a combination of abiotic and biotic stress (Villareal, 2013). The author concludes that the obstruction of the vessels by the fungus and the impediment of the absorption of water and nutrients by these stressful conditions cause the closure of stomata and a decrease of photosynthesis.

\section{Drought}

Water deficit stress in the cape gooseberry reduces the longitudinal growth of the reproductive organs, damaging the amount of fruit produced (due to the lower number of "productive knots"), and, also, affecting the filling of the fruit by reducing the leaf area (Fischer and Melgarejo, 2014). When this stress occurs at the beginning of production it produces smaller fruits leading to reduced productivity and a greater sensitivity to fruit cracking. This indicates that these organs are more susceptible to a lack of water when they are in the cell division (Torres et al., 2004).

Moreno (2013) subjected cape gooseberry plants to 90 and $17 \%$ of the field capacity (in plastic pot), finding that the water deficit markedly reduces vegetative growth, chlorophyll content, gas exchange parameters, as well as the fluorescence of chlorophyll a. This author also records the effect of water deficit stress on plants from $14 \mathrm{~d}$ and is much greater after $21 \mathrm{~d}$ with increased leaf temperature, loss of electrolytes, and increased concentration of antioxidant enzymes such as catalase and peroxidase and also of the proline osmolyte

Knowing the cape gooseberry's reaction to water deficit stress that occurs in many cases under higher than optimal temperatures, it is very likely that stomatal conductance and transpiration are reduced, and this increases leaf temperature and photorespiration and, consequently, photosynthesis and the growth and production of the plant are reduced (Restrepo-Díaz et al., 2010). This scenario becomes more likely with increasing global warming (Menezes-Silva et al., 2019; Ngasoh et al., 2019).

\section{Salinity}

Like other nightshades, cape gooseberry not only shows a moderate tolerance to salinity, but also concentrations of $30 \mathrm{mM} \mathrm{NaCl}$ in the nutrient solution increases growth rates such as CGR (crop growth rate), RGR (relative growth rate), NAR (net assimilation rate) and LAI (leaf area index) (Miranda et al., 2010).

The cape gooseberry is protected from saline conditions through mechanisms such as increased total 
antioxidant activity in plants subjected to concentrations of $120 \mathrm{mM} \mathrm{NaCl}$ that significantly increased the activity of oxygen free radical control, compared to plants subjected to $60 \mathrm{mM}$ (Miranda et al., 2014). Also, these authors observe an increasing tendency for the osmoprotectant proline when the salt concentration increased. Nimbolkar et al. (2020) state that the understanding of a salt tolerance mechanism in plant tissues is important for the integration of physiological and biochemical comprehension for increasing the salinity tolerance of fruit species.

This moderate tolerance of cape gooseberry is very similar to many tomato varieties (Chakma et al., 2019) and is important in the scenario of increased saline areas generated by anthropogenic effects or by factors related to climate change (Ngasoh et al., 2019).

\section{Table 2. Effect of $\mathrm{NaCl}$ salinity on total antioxidant activity ( $\mu \mathrm{M}$ Fremy's salt/g fresh weight) in leaf tissue of cape gooseberry plants, $\mathbf{4 5}$ and $\mathbf{7 5} \mathrm{d}$ after plantat- ing (Miranda et al., 2014).}

\begin{tabular}{|l|c|c|c|c|}
\hline \multirow{2}{*}{$\begin{array}{c}\text { NaCl } \\
(\mathrm{mM})\end{array}$} & \multicolumn{4}{|c|}{ Days after planting } \\
\cline { 2 - 5 } & 45 & 55 & 65 & 75 \\
\hline 0 & $2.72 \mathrm{bC}$ & $3.16 \mathrm{bB}$ & $3.15 \mathrm{bB}$ & $3.46 \mathrm{bA}$ \\
\hline 60 & $2.74 \mathrm{bC}$ & $3.17 \mathrm{bB}$ & $3.29 \mathrm{bB}$ & $3.78 \mathrm{abA}$ \\
\hline 120 & $3.28 \mathrm{aC}$ & $3.84 \mathrm{aB}$ & $4.18 \mathrm{aA}$ & $4.14 \mathrm{aA}$ \\
\hline
\end{tabular}

Means in columns followed by the same letter are not significantly different according to Tukey's test $(P \leq 0.05)$. Lowercase letters are for comparing the $\mathrm{NaCl}$ concentration and uppercase between the days of the sample.

\section{Wind}

Cape gooseberry plantations suffer from strong winds (Carrillo-Perdomo et al., 2015), causing water loss due to evapotranspiration, deformation of the plant structure, and stagnation of growth that can also cause premature reproductive organ abscission (Fischer and Melgarejo, 2014). This is why in windy places plant barriers that cut the wind are necessary. Winds with speeds $>30 \mathrm{~km} \mathrm{~h}^{-1}$ prevent the flight of bees, which are important due to entomophilic pollination for cape gooseberry (National Research Council, 1989). Likewise, wind dries out the stigma of the flowers, disabling pollination. In general, hot winds accelerate the drying of the plant tissues, replacing the humid air in the intercellular spaces with dry air (Das, 2012).

The benefits of soft winds to the physiology of the cape gooseberry are great, not only because of the transfer of mass and heat (Gariglio et al., 2007), but also because they dry the plants after a rain and ensure the opening of stomata (Fischer and Melgarejo, 2014). At the same time soft winds renew the air in the canopy maintaining the required $\mathrm{CO}_{2}$ concentration for stable photosynthesis (Fischer and OrduzRodríguez, 2012) and they favor gas exchange in the low and dense strata of the plant (Das, 2012). Friedrich and Fischer (2000) observe in fruit trees that winds as slow as $1.7 \mathrm{~m} \mathrm{~s}^{-1}$ are the most optimal for producing DM.

\section{CONCLUSIONS}

As a typical Andean plant, the cape gooseberry adapts to a wide range of cold altitudinal climate, with base temperatures (minimum) for the stems $\left(6.3^{\circ} \mathrm{C}\right)$ and fruit growth $\left(1.9^{\circ} \mathrm{C}\right)$ being relatively low. The plant cannot stand temperatures $<0^{\circ} \mathrm{C}$ because of the burning of leaves, young shoots, flowers, calices and young fruits.

The Andean conditions of the tropics that include high solar radiation and rather short day lengths favor the beginning of flowering. Important for fruit filling and quality is solar radiation that stimulates the green calyx and the two adjacent leaves. The cape gooseberry can be classified as a light-demanding plant, requiring from 1,500 to $2,000 \mathrm{~h}$ direct sunlight/year.

As a plant with an indeterminate growth habit, a constant supply of water is essential, while high amounts of water cause cracking of the fruits, and the plant does not tolerate waterlogging for more than $4 \mathrm{~d}$. The cape gooseberry is classified as a moderately tolerant plant to salinity that has mechanisms such as increased antioxidant activity and proline accumulation for its protection. Increasing wind speeds with altitude can affect plantations so that plant barriers are necessary.

To our knowledge, no studies have been reported on the effects of elevated atmospheric concentrations of $\mathrm{CO}_{2}$ on the physiology and growth of the Andean solanaceous fruit plants except tomato.

Conflict of interests: The manuscript was prepared and reviewed with the participation of the authors, who declare that there exists no conflict of interest that puts at risk the validity of the presented results. 


\section{BIBLIOGRAPHIC REFERENCES}

Aguilar-Carpio, C., P. Juárez-López, I.H. Campos-Aguilar, I. Alia-Tejacal, M. Sandoval-Villa, and V. López-Martínez. 2018. Analysis of growth and yield of cape gooseberry (Physalis peruviana L.) grown hydroponically under greenhouse conditions. Rev. Chapingo Ser. Hortic. 24(3), 191-202. Doi: 10.5154/r.rchsh.2017.07.024

Agronet. 2019. Producción nacional por producto: Uchuva. In: https://www.agronet.gov.co/Documents/39-UCHUVA_2017.pdf; consulted: November, 2019.

Akbaba, U. 2019. Elements identification in golden strawberries (Physalis peruviana L.) using wavelength dispersive X-Ray fluorescence. Turk. J. Agric. Food Sci. Technol. 7(6), 851-855. Doi: 10.24925/turjaf. v7i6.851-855.2386

Aldana, F., P.N. García, and G. Fischer. 2014. Effect of waterlogging stress on the growth, development and symptomatology of cape gooseberry (Physalis peruviana L.) plants. Rev. Acad. Colomb. Cienc. Exact. Fis. Nat. 38(149), 393-400. Doi: 10.18257/raccefyn.114

Alvarado, P.A., C.A. Berdugo, and G. Fischer. 2004. Efecto de un tratamiento a $1,5^{\circ} \mathrm{C}$ y dos humedades relativas sobre las características físico-químicas de frutos de uchuva Physalis peruviana L. durante el posterior transporte y almacenamiento. Agron. Colomb. 22(2), 147-159.

Álvarez-Herrera, J., H. Balaguera-López, and G. Fischer. 2012. Effect of irrigation and nutrition with calcium on fruit cracking of the cape gooseberry (Physalis peruviana $\mathrm{L}$.) in the three strata of the plant. Acta Hortic. 928, 163-170. Doi: 10.17660/ActaHortic.2012.928.19

Álvarez-Herrera, J., G. Fischer, and J.E. Vélez-Sánchez. 2015. Producción de frutos de uchuva (Physalis peruviana L.) bajo diferentes láminas de riego, frecuencias de riego y dosis de calcio. Rev. Colomb. Cienc. Hortic. 9(2), 222-233. Doi: 10.17584/rcch.2015v9i2.4177

Alvarez-Herrera, J., H. González, and G. Fischer. 2019. Water potential in cape gooseberry (Physalis peruviana L.) plants subjected to different irrigation treatments and doses of calcium. Agron. Colomb. 37(3), 274-282. Doi: 10.15446/agron.colomb.v37n3.79935

Aparecido, L.E., R.M. Batista, R. Moraes, C.T.S. Costa, and A.F. Moraes-Oliveira. 2019. Agricultural zoning of climate risk for Physalis peruviana cultivation in Southeastern Brazil. Pesqu. Agropecu. Bras. 54, e00057. Doi: 10.1590/s1678-3921.pab2019.v54.00057

Baldwin, J.W., J.B. Dessy, G.A. Vecchi, and M. Oppenheimer. 2019. Temporally compound heat wave events and global warming: an emerging hazard. Earth's Future 7, 411-427. Doi: 10.1029/2018EF000989

CABI Invasive Species Compendium. 2019. Physalis peruviana (Cape gooseberry). Detailed coverage of invasive species threatening livelihoods and the environment worldwide. CAB International, Wallingford, UK.

Cardona, W.A., L.G. Bautista-Montealegre, N. Flórez-Velasco, and G. Fischer. 2016. Desarrollo de la biomasa y raíz en plantas de lulo (Solanum quitoense var. septentrionale) en respuesta al sombrío y anegamiento. Rev. Colomb. Cienc. Hortic. 10(1), 53-65. Doi: 10.17584/ rcch.2016v10i1.5124

Carillo-Perdomo, E., A. Aller, S.M. Cruz-Quintana, F. Giampieri, and J.M. Alvarez-Suarez. 2015. Andean berries from Ecuador: A review on botany, agronomy, chemistry and health potential. J. Berry Res. 5, 49-69. Doi: 10.3233/JBR-140093

Chakma, P., M. Hossain, and G. Rabbani. 2019. Effects of salinity stress on seed germination and seedling growth of tomato. J. Bangladesh Agril. Univ. 17(4), 490499. Doi: 10.3329/jbau.v17i4.44617

Cleves-Leguízamo, J.A., J. Toro-Calderón, L. Martínez-Bernal, and T. León-Sicard. (2017). La Estructura Agroecológica Principal (EAP): novedosa herramienta para planeación del uso de la tierra en agroecosistemas. Rev. Colomb. de Cienc. Hortic. 11(2), 441-449. Doi: 10.17584/rcch.2017v11i2.7350

Cooman, A., C. Torres, and G. Fischer. 2005. Determinación de las causas del rajado del fruto de uchuva (Physalis peruviana L.) bajo cubierta: II. Efecto de la oferta de calcio, boro y cobre. Agron. Colomb. 23 (1), 74-82.

Das, H.P. 2012. Agrometeorology in extreme events and natural disasters. BS Publications, Hyderabad, India.

Dhankher, O.M. and C.H. Foyer. 2018. Climate resilient crops for improving global food security and safety. Plant Cell Environ. 41, 877-884. Doi: 10.1111/ pce. 13207

Diniz, F.O., L. Chamma, and A.D.L.C. Novembre. 2020. Germination of Physalis peruviana L. seeds under varying conditions of temperature, light, and substrate. Rev. Ciênc. Agron. 51(1), e20166493. Doi: 10.5935/1806-6690.20200003

Dostert, N., J. Roque, A. Cano, M.I. La Torre, and M. Weigend. 2012. Hoja botánica: Aguaymanto - Physalis peruviana L. Technical Report. Proyecto Perúbiodiverso, Lima.

Dwivedi, P. and R.S. Dwivedi. 2012. Physiology of abiotic stress in plants. Agrobios, Jodhpur, India.

Fischer, G. 1995. Effect of root zone temperature and tropical altitude on the growth, development and fruit quality of cape gooseberry (Physalis peruviana L.). $\mathrm{PhD}$ thesis. Humboldt-Universität zu Berlin, Berlin, Germany.

Fischer, G. 2000a. Crecimiento y desarrollo. pp. 9-26. In: Flórez, V.J., G. Fischer, and A.D. Sora (eds.). Producción, poscosecha y exportación de la uchuva (Physalis peruviana L.). Unibiblos, Universidad Nacional de Colombia, Bogota. 
Fischer, G. 2000b. Ecophysiological aspects of fruit growing in tropical highlands. Acta Hortic. 531, 91-98. Doi: 10.17660/ActaHortic.2000.531.13

Fischer, G. 2005. El problema del rajado del fruto de uchuva y su posible control. pp. 55-82. In: Fischer, G., D. Miranda, W. Piedrahita, and J. Romero (eds.). Avances en cultivo, poscosecha y exportación de la uchuva (Physalis peruviana L.) en Colombia. Unibiblos, Universidad Nacional de Colombia, Bogota.

Fischer, G. 2019. La ecofisiología como una herramienta para el manejo de los cultivos. In: Conferencia en Seminario de Actualización Académica en Ciencias Agrícolas y Veterinarias. Universidad Pedagógica y Tecnológica de Colombia, Tunja, Colombia.

Fischer, G., P.J. Almanza-Merchán, and D. Miranda. 2014. Importancia y cultivo de la uchuva (Physalis peruviana L.). Rev. Bras. Frutic. 36(1), 1-15. Doi: 10.1590/0100-2945-441/13

Fischer, G., G. Ebert, and P. Lüdders. 2000a. Root-zone temperature effects on dry matter distribution and leaf gas exchange of cape gooseberry (Physalis peruviana L.). Acta Hortic. 531, 169-173. Doi: 10.17660/ ActaHortic.2000.531.24

Fischer, G., G. Ebert, and P. Lüdders. 2000b. Provitamin A, carotenoids, organic acids and ascorbic acid content of cape gooseberry (Physalis peruviana L.) ecotypes grown at two tropical altitudes. Acta Hortic. 531, 263267. Doi: 10.17660/ActaHortic.2000.531.43

Fischer, G., G. Ebert, and P. Lüdders. 2007. Production, seeds and carbohydrate contents of cape gooseberry (Physalis peruviana L.) fruits grown at two contrasting Colombian altitudes. J. Appl. Bot. Food Qual. 81(1), 29-35.

Fischer, G., A. Herrera, and P.J. Almanza. 2011. Cape gooseberry (Physalis peruviana L.). pp. 374-396. In: Yahia, E.M. (ed.) Postharvest biology and technology of tropical and subtropical fruits. Vol. 2: Acai to citrus. Woodhead Publishing, Cambridge, UK. Doi: 10.1533/9780857092762.374

Fischer, G. and O. Martínez. 1999. Calidad y madurez de la uchuva (Physalis peruviana L.) en relación con la coloración del fruto. Agron. Colomb. 16(1-3), 35-39.

Fischer, G., L.M. Melgarejo, and J. Cutler. 2018. Pre-harvest factors that influence the quality of passion fruit: A review. Agron. Colomb. 36(3), 217-226. Doi: 10.15446/ agron.colomb.v36n3.71751

Fischer, G. and L.M. Melgarejo. 2014. Ecofisiología de la uchuva (Physalis peruviana L.). pp. 31-47. In: Carvalho, C.P. and D.A. Moreno (eds.). Physalis peruviana: fruta andina para el mundo. Programa Iberoamericano de Ciencia y Tecnología para el Desarrollo - CYTED, Limencop SL, Alicante, Spain.

Fischer, G. and D. Miranda. 2012. Uchuva (Physalis peruviana L.). pp. 851-873. In: Fischer, G. (ed.). Manual para el cultivo de frutales en el trópico. Produmedios, Bogota.
Fischer, G. and J.O. Orduz-Rodríguez. 2012. Ecofisiología en los frutales. pp. 54-72. In: Fischer, G. (ed.). Manual para el cultivo de frutales en el trópico. Produmedios, Bogota.

Fischer, G., F. Ramírez, and F. Casierra-Posada. 2016. Ecophysiological aspects of fruit crops in the era of climate change. A review. Agron. Colomb. 34(2), 190-199. Doi: 10.15446/agron.colomb.v34n2.56799

Fischer, G., C. Ulrichs, and G. Ebert. 2015. Contents of non-structural carbohydrates in the fruiting cape gooseberry (Physalis peruviana L.) plant. Agron. Colomb. 33(2), 155-163. Doi: 10.15446/agron.colomb. v33n2.51546

Friedrich, G. and M. Fischer. 2000. Physiologische Grundlagen des Obstbaues. Verlag Eugen Ulmer, Stuttgart, Germany.

Gariglio, N.F., R.A. Pilatti, and M. Agustí. 2007. Requerimientos ecofisiológicos de los árboles frutales. pp. 41-82. In: Sozzi, G.O. (ed.). Árboles frutales: ecofisiología, cultivo y aprovechamiento. Editorial Facultad de Agronomía, Universidad de Buenos Aires, Buenos Aires.

Garzón-Acosta, C.P., D.M. Villarreal-Garzón, G. Fischer, A.O. Herrera, and D. Sanjuanelo. 2014. La deficiencia de fósforo, calcio y magnesio afecta la calidad poscosecha del fruto de uchuva (Physalis peruviana L.). Acta Hortic. 1016, 83-88. Doi: 10.17660/ ActaHortic.2014.1016.9

Gordillo, O., G. Fischer, and R. Guerrero. 2004. Efecto del riego y de la fertilización sobre la incidencia del rajado en frutos de uchuva (Physalis peruviana L.) en la zona de Silvania (Cundinamarca). Agron. Colomb. 22(1), 53-62.

Heinze, W. and M. Midash. 1991. Photoperiodische Reaktion von Physalis peruviana L. Gartenbauwiss. 56(6), 262-264.

Kulandaivelu, G., S. Maragatham, and N. Nedunchezhian. 1989. On the possible control of ultraviolet-B induced response in growth and photo-synthetic activities in higher plants. Physiol. Plant. 76, 398-404. Doi: 10.1111/j.1399-3054.1989.tb06210.x

Lambers, H., F.S. Chapin III, F. Stuart, and T.L. Pons. 2008. Plant physiological ecology. Springer, New York, NY. Doi: 10.1007/978-0-387-78341-3

Marengo, J.A., J.D. Pabón, A. Díaz, G. Rosas, G. Ávalos, E. Montealegre, M. Villacis, S. Solman, and M. Rojas. 2011. Climate change: evidence and future scenarios for the Andean region. pp. 110-127. In: Herzog, S., R. Martinez, P.M. Jorgensen, and H. Tiessen (eds.). Climate change and biodiversity in the tropical Andes. IAI-SCOPE-UNESCO, Paris.

Mayorga, M., G. Fischer, L.M. Melgarejo, and A. Parra-Coronado. 2020. Growth, development and quality of Passiflora tripartita var. mollissima fruits under two 
environmental tropical conditions. J. Appl. Bot. Food Qual. 93(1), 66-75. . Doi: 10.5073/JABFO.2020.093.009

Mazorra, M.F., A.P. Quintana, D. Miranda, G. Fischer, and B. Cháves. 2003. Análisis sobre el desarrollo y la madurez fisiológica del fruto de la uchuva (Physalis peruviana L.) en la zona de Sumapaz (Cundinamarca). Agron. Colomb. 21(3), 175-189.

Menezes-Silva, P.E., L. Loram Lourenço, R.D. Alves, L. Sousa, S.E. Almeida, and F. Farnese. 2019. Different ways to die in a changing world: consequences of climate change for tree species performance and survival through an ecophysiological perspective. Ecol. Evol. 9(20), 11979-11999. Doi: 10.1002/ece3.5663

Miranda, D., G. Fischer, I. Mewis, S. Rohn, and C. Ulrichs. 2014. Salinity effects on proline accumulation and total antioxidant activity in leaves of the cape gooseberry (Physalis peruviana L.). J. Appl. Bot. Food Qual. 87, 67-73.

Miranda, D., G. Fischer, and C. Ulrichs. 2010. Growth of cape gooseberry (Physalis peruviana L.) plants affected by salinity. J. Appl. Bot. Food Qual. 83(2), 175-181.

Mittler, R. 2006. Abiotic stress, the field environment and stress combination. Trends Plant Sci. 11, 15-19. Doi: 10.1016/j.tplants.2005.11.002

Mora, R., A. Peña, E. López, J.J. Ayala, and D. Ponce. 2006. Agrofenología de Physalis peruviana L. en invernadero y fertirriego. Rev. Chapingo Ser. Hortic. 12(1), 57-63. Doi: 10.5154/r.rchsh.2005.10.011

Moreno, D. 2013. Caracterización de parámetros fisiológicos y bioquímicos en tres accesiones de uchuva (Physalis peruviana L.) sometidas a estrés hídrico controlado. Undergraduate thesis. Faculty of Agricultural Sciences, Universidad Nacional de Colombia, Bogota.

National Research Council. 1989. Lost crops of the Incas. National Academy Press, Washington, D.C. pp. 241-251.

Ngasoh, F.G., E.A. Jandong, P.A. Dauda, and R. Ismaila. 2019. The influence of climate variation on abiotic plant stress: a review. Int. J. Environ. Agric. Biotech. 4(4), 1153-1160. Doi: 10.22161/ijeab.4440

Nimbolkar, P.K., J. Bajeli, A. Tripathi, A.K. Chaubey, and N.M. Kanade. 2020. Mechanism of salt tolerance in fruit crops: a review. Agric. Rev. 41(1), 25-33. Doi: 10.18805/ag.R-1919

Nocetti, D., H. Núñez, L. Puente, A. Espinosae, and F. Romeroa. 2020. Composition and biological effects of goldenberry byproducts: an overview. J. Sci. Food Agric. 2020. Doi: 10.1002/jsfa.10386

Nunes, A.L., S. Sossmeier, A.P. Got, and N.B. Bispo. 2018. Germination eco-physiology and emergence of Physalis peruviana seedlings. J. Agric. Sci. Technol. B 8, 352359. Doi: 10.17265/2161-6264/2018.06.002
Opara, L.U., C.J. Studam, and N.H. Banks. 1997. Fruit skin splitting and cracking. Hortic. Rev. 19, 217-262. Doi: 10.1002/9780470650622.ch4

Pacheco, R.A. and H.F. Sáenz. 1991. Influencia de la temperatura e intensidad lumínica en condiciones controladas sobre el crecimiento foliar y radical en dos ecotipos de Uchuva Physalis peruviana L. en Tunja. Undergraduate thesis. Faculty of Agronomy, Universidad Pedagógica y Tecnológica de Colombia, Tunja, Colombia.

Parra, A., G. Fischer, and B. Chaves. 2015. Tiempo térmico para estados fenológicos reproductivos de la feijoa (Acca sellowiana (O. Berg) Burret). Acta Biol. Colomb. 20(1), 167-177.

Peet, M.M. 2009. Physiological disorders in tomato fruit development. Acta Hortic. 821, 151-160. Doi: 10.17660/ ActaHortic.2009.821.16

Puente, L., D. Nocetti, and A. Espinosa. 2019. Physalis peruviana Linnaeus, an update on its functional properties and beneficial effects in human health. In: Mariod, A. (ed.). Wild fruits: Composition, nutritional value and products. Springer Nature, Switzerland. Doi: 10.1007/978-3-030-31885-7_34

Ramadan, M.F. and J.-T. Mörsel. 2019. Goldenberry (Physalis peruviana) oil. pp. 397-404. In: Fruit oils: chemistry and functionality, Springer Nature Switzerland AG, Switzerland. Doi: 10.1007/978-3-030-12473-1_19

Ramírez, F., G. Fischer, T.L. Davenport, J.C.A. Pinzón, and C. Ulrichs. 2013. Cape gooseberry (Physalis peruviana L.) phenology according to the $\mathrm{BBCH}$ phenological scale. Sci. Hortic. 162, 39-42. Doi: 10.1016/j. scienta.2013.07.033

Restrepo-Díaz, H., J.C. Melgar, and L. Lombardini. 2010. Ecophysiology of horticultural crops: an overview. Agron. Colomb. 28(1), 71-79.

Rodríguez, N.C. and M.L. Bueno. 2006. Estudio de la diversidad citogenética de Physalis peruviana L. (Solanaceae). Acta Biol. Colomb. 11(2), 75-85.

Salazar, M.R., B. Chaves-Córdoba, J.W. Jones, and A. Cooman. 2006. A simple phenological and potential production model for cape gooseberry (Physalis peruviana L.). Acta Hortic. 718, 105-112. Doi: 10.17660/ ActaHortic.2006.718.11

Salazar, M.R., J.W. Jones, B. Chaves, A. Cooman, and G. Fischer. 2008. Base temperature and simulation model for nodes appearance in cape gooseberry (Physalis peruviana L.). Rev. Bras. Frutic. 30(4), 862-867. Doi: 10.1590/S0100-29452008000400004

Sánchez-Reinoso, A.D., Y. Jiménez-Pulido, J.P. Martínez-Pérez, C.S. Pinilla, and G. Fischer. 2019. Chlorophyll fluorescence and other physiological parameters as indicators of waterlogging and shadow stress in lulo (Solanum quitoense var. septentrionale) seedlings. Rev. Colomb. Cienc. Hortic. 13(3), 325-335. Doi: 10.17584/ rcch.2019v13i3.10017 
Shukla, P.R., J. Skea, R. Slade, R. van Diemen, E. Haughey, J. Malley, M. Pathak, and J. Portugal Pereira (eds.). 2019. Technical summary, 2019. In: Climate change and land: an IPCC special report on climate change, desertification, land degradation, sustainable land management, food security, and greenhouse gas fluxes in terrestrial ecosystems. IPCC; https://www.ipcc. ch/site/assets/uploads/sites/4/2019/11/03_Technical-Summary-TS.pdf; consulted: March, 2020.

Taiz, L. and E. Zeiger. 2010. Plant physiology. $5^{\text {th }}$ ed. Sinauer Associates, Sunderland, MA.

Torres, C., A. Cooman, and G. Fischer. 2004. Determinación de las causas del rajado del fruto de uchuva (Physalis peruviana L.) bajo cubierta: I. Efecto de la variación en el balance hídrico. Agron. Colomb. 22(2), 140-146.

Torres, C., G. Fischer, and D. Miranda. 2016. Principales fisiopatías del cultivo de uchuva (Physalis peruviana L.). pp. 139-146. In: Miranda, D., C. Carranza, and G. Fischer (eds.). Problemas de campo asociados al cultivo de uchuva (Physalis peruviana L.). Editorial Universidad Nacional de Colombia, Bogota.

Trevisani, N., R.C. De Melo, M.P. Colli, J.L.M. Coimbra, and A.F. Guidolin. 2017. Associations between traits in fisális: a tool for indirect selection of superior plants. Rev. Bras. Frutic. 39(4), e-106. Doi: 10.1590/0100-29452017106

UNEP, United Nations Environment Programme. 2019. Emissions Gap Report 2019. Global progress report on climate action. In: https://www.unenvironment. org/resources/emissions-gap-report-2019; consulted: February, 2020.

Villareal, A.P. 2013. Evaluación fisiológica de plantas de uchuva (Physalis peruviana L.), en la respuesta al estrés por anegamiento e infección de Fusarium oxysporum. MSc thesis. Faculty of Agricultural Sciences, Universidad Nacional de Colombia, Bogota.

Villareal-Navarrete, A., G. Fischer, L.M. Melgarejo, G. Correa, and L. Hoyos-Carvajal. 2017. Growth response of the cape gooseberry (Physalis peruviana L.) to waterlogging stress and Fusarium oxysporum infection. Acta Hortic. 1178, 161-168. Doi: 10.17660/ ActaHortic.2017.1178.28

Wolff, X.Y. 1991. Species, cultivar, and soil amendments influence fruit production of two Physalis species. HortScience 26(12), 1558-1559. 